\title{
O przyjemności lektury
}

\section{Justyna Pomierska, Przysłowia kaszubskie. Studium z paremiografii i paremiologii, Instytut Kaszubski w Gdańsku, Gdańsk 2013, 696 s.}

W kraju, w którym folklorystyka nie ma statusu dziedziny naukowej i w czasach zdominowanych przez głośny dyskurs zabierający jej prawo do ciągłości ${ }^{1}$, rozprawa Justyny Pomierskiej - filolożki, folklorystki, paremiolożki, kaszubolożki - zachwyca. Podziw budzi nie tyle liczba stron (696), choć i ona zasługuje na uznanie i wyróżnienie, ile lekkość wywodu połączona z precyzją badawczą. Autorka, co wyraźnie widać na każdej stronie omawianej monografii, ma umiejętność porządkowania ogromnego materiału źródłowego i interpretacyjnego doboru prac krytycznych. Trafny i jasny przekaz, choć cechujący się pedanterią językową, nie jest przeznaczony wyłącznie dla odbiorcy naukowego. Pracę gdańskiej folklorystki z przyjemnością przeczyta każdy, kto interesuje się problematyką kaszubską, paremiologiczną czy szerzej literaturą ustną.

Dwudzielna struktura Studium z paremiografii i paremiologii wynika ze specyfiki źródeł, którym autorka Przësłowié samò sã rodzy w głowie (Pomierska 2002, 2010) poświęca uwagę badawczą. Rozproszone przestrzennie i temporalnie zapisy folkloru słownego, opatrzone różnymi, często lapidarnymi komentarzami odnoszącymi się do kontekstu wykonania i przy odmiennym wykorzystaniu znaków interpunkcyjnych jako zamienników dla cech prymarnych werbalizacji (cf. Pomierska 2013: 44), słusznie zaowocowały podziałem na część eksplanacyjną (monografię) i deskryptywną (materiały). Należy podkreślić, że zbiór paremii zawarty w Księdze przysłów kaszubskich (s. 345-696) nie może być w żadnym

${ }^{1}$ Wykaz prac podejmujących kwestię groźby utraty przez folklorystykę ciągłości znajduje się np. w: Rękas 2014. 
razie uznany za mniej pracochłonny czy niżej wartościowany naukowo od segmentu interpretacyjnego. Trud włożony w przygotowanie zbioru, klasyfikację, odpowiedni zapis i indeks haseł pomocniczych równy jest niepodważalnej wartości poznawczej całej publikacji i jej bezsprzecznej aktualności zarówno naukowej, jak i popularyzatorskiej. Podobny zabieg - z równie dobrym i studyjnie płodnym skutkiem - zastosowała także w zeszłorocznej serii Agnieszka Przybyła-Dumin (2013a; 2013b; 2013c), a historię jego wykorzystywania $\mathrm{w}$ folklorystyce i etnografii rozpoczyna okres rozchodzenia się dróg badaczy terenowych i gabinetowych. Justyna Pomierska z sukcesem łączy obie metody pracy eksploratora tekstów kultury, oprowadzając czytelnika po kolejnych, sukcesywnie wprowadzanych i rozszerzanych polach analitycznych.

Wyniki badań eksplanacyjnych przedstawione są w sześciu rozdziałach, zatytułowanych kolejno: Wstęp, Dzieje paremiografii kaszubskiej, Przysłowia w literaturze kaszubskiej, Opis zawartości „Księgi przysłów kaszubskich”, Utrwalony w przysłowiu obraz XIX-wiecznej wsi kaszubskiej oraz Językowy artyzm przystów. Na pierwszy z nich składa się m.in. szczegółowo opisany stan badań nad przysłowioznawstwem kaszubskim w kontekście folklorystyki i etnografii polskiej. Szczególny nacisk, obok precyzyjnie wytyczonych ram źródłowych, autorka kładzie na znaczenie prawidłowej i konsekwentnie stosowanej kaszubskiej pisowni paremii. Wiele uwagi, ukierunkowanej wyraźnie interpretacyjnie, poświęca także pojęciu przysłowia $\mathrm{w}$ powiązaniu $\mathrm{z}$ frazeologizmem i innymi gatunkami folkloru słownego. Na podkreślenie zasługują rozważania wpisujące pracę filolożki w dyskurs genologiczny. Autorka, nie ulegając pokusie jednoznacznych ocen i pochopnych wniosków, z wielką pokorą badawczą, sprawnie, wręcz z łatwością mówi o trudnej i wymagającej żmudnych studiów materii klasyfikacyjnej.

Historia zapisów kaszubskich przysłów, pozornie - przy nieuważnym kartkowaniu publikacji - sprawozdawcza, może być przykładem wzorowego zastosowania narzędzi analitycznych do materii przeglądowej. Każdy fragment o charakterze referującym jest oparty na jasnym i zrozumiałym dla czytelnika zamyśle krytycznym. Odbiór ułatwiają grafiki (koliste wykresy), ukazujące zestawienia procentowe przysłów ekscerpowanych podczas kwerend na różnym materiale źródłowym. Wyłuskując paremia z prasy kaszubskiej, badaczka płynnie włącza do rozważań dokumentalnych 
teorię bajki ludowej. Umożliwia to czytelnikowi (odbiorcy) przeniesienie wyników jej badań archiwalnych na analizy bajki (z funkcją ludyczną i edukacyjną) wykorzystujące specyfikę sposobów informowania społeczeństwa oraz kształtowania jego postaw (cf. Maślanka 1976: 168; Pisarek 2006: 154-155). Dobór materiału bajkowego w wydawnictwach drukowanych periodycznie jest wynikiem ich aktualności, wszechstronności, publicznego charakteru i wiarygodności (cf. Maślanka 1976: 36), dlatego bardzo ważne jest wyszczególnienie przez autorkę Studium z paremiografii i paremiologii tytułów gazet oraz miejsc i okoliczności ich wydawania. Wyraźne jest tworzenie nowej jakości dla bajki ludowej. Dzięki publikacji w najbardziej pedagogicznym środku komunikowania masowego (nie ma W nim „ulotności” charakteryzującej media audialne, audiowizualne oraz Internet), kaszubska bajka ludowa w odbiorze czytelniczym zyskała na dydaktyzmie oraz powtarzalności (nie mówiąc już o wpływie na literaturę pisaną). Wykorzystano więc następujące cechy prasy:

1) ważny składnik środowiska wychowawczego rozumianego jako ogół wpływów zasadniczo nieświadomych i niezamierzonych, korzystnych i niekorzystnych;

2) medium, w którym problemy moralne zwracają na siebie o wiele większą uwagę niż w innych mediach masowych;

3) zdolność skutecznego wpływania na człowieka w warstwie kulturalnej, w obrębie której formowane są postawy społeczne (cf. Lepa 2001: 64).

Zgodnie z praktyką Samuela Adalberga, zastosowaną w Księdze przysłów, przypowieści i wyrażeń przysłowiowych polskich (Adalberg 19891994), folklorystka włącza „do bazy źródłowej paremiografii kaszubskiej dokona[nia] piśmiennictwa kaszubskiego”, co „ma oczywiste uzasadnienie w tym, że literatura piękna, twórczość literacka jest naturalnym środowiskiem, w którym rozwija się język" (Pomierska 2013: 153). Szczególną uwagę poświęca utworom: Rozmòwa Pòlôcha z Kaszëba. Rozmòwa Kaszëbë z Pòlôchã Floriana Ceynowy, Ò Panu Czôrlińsczim, co do Pùcka pò sécë jachôł Hieronima Derdowskiego, Sowizdrzôł ù Krëbanów Jana Karnowskiego, Dobrogòst i Miłosława. Kaszëbsczé spiéwë dzejowé w trzech brawãdach Leona Heyke, Jôchim Czwaruch i Gôdka ò Januszu Skwierkù Franciszka Sędzickiego, Dokôzë Alojzego Budzisza oraz dziełom Aleksandra Majkowskiego, felietonom Aleksandra Labudy i dramatom Bernarda Sychty. Trzysta sześćdziesiąt przysłów wypisanych z materii literackiej 
(przy niewielkiej liczbie nowych, oryginalnych), kluczowych dla autorki omawianej rozprawy, podlega analizie co do momentu werbalizacji i okoliczności użycia. Jak podkreśla badaczka: „literackie realizacje (...) wprowadzają przysłowie-wypowiedzenie w szerszy kontekst i konstytuację, przez co upewniają w interpretacji wielu paremii, a liczny zbiór daje potwierdzenie powszechnej znajomości dla przysłów notowanych w zbiorach jednostkowo" (Pomierska 2013: 177).

Kolejny rozdział części monograficznej to wzorcowa ilustracja odejścia od modeli ekskluzywistycznych na rzecz powiązań źródłowych, fenomenu przenikania się, nieznającej granic narodowych, państwowych, językowych, etnicznych, religijnych itd. materii folkloru słownego. W Opisie zawartości czytelnik otrzymuje krytyczny wykaz geograficznych powiązań przysłów kaszubskich, reprezentowany przez zbieżności kaszubsko-cieszyńskie, śląskie, małopolskie, mazowieckie, wielkopolskie i kociewskie. Całościowy obraz dopełniają informacje o wieku paremii, uwzględniające ich żywotność i możliwości asymilacyjne. Dzięki takiej ewaluacji materiału możliwe jest płynne przejście do jądra tej rozprawy - w moim przekonaniu - jej istoty, która kryje się w rozważaniach dotyczących artyzmu językowego przysłowia i utrwalonego w nim obrazu dziewiętnastowiecznej wsi. Odnajdując złoty środek między filologicznie i etnograficznie zorientowaną folklorystyką, filolożka znajduje punkt oparcia w kluczowym dla folkloru synkretyzmie i buduje na nim analizę (pseudo)deskrypcji przysłów. Fenomen ten widać na przykładach pogrupowanych w następujący sposób: Wiedza o człowieku i świecie; Stosunek do wiary katolickiej i polskości oraz Życie rodzinne i towarzyskie. Badaczka, prowadząc analizy w ramach tego podziału, niezmiennie uwzględnia zarówno tę część spuścizny paremiologicznej, w której dosłowny sens weszły zarówno elementy wiążące się z obrazem świata, jak i takie, których związki z nim widoczne są jedynie na płaszczyźnie znaczenia przenośnego ze świadomością, iż przysłowie wchodzi w silną zależność od kontekstu (cf. Bartmiński 1990: 19). „Fakt, że przysłowia zostały zapisane przez zbieraczy w oderwaniu od kontekstu, nie oznacza wcale, że w praktyce są one wypowiadane w izolacji (...), żadnego przysłowia i żadnego porzekadła nie przytacza się samoistnie, lecz zawsze w określonym kontekście" (Chitima 1983: 365). Pozwala to na uniknięcie podziału nadającego sensowi wtórnemu wartość nadrzędną w stosunku do dosłownego, ponieważ 
w samym poszukiwaniu znaczenia przysłowia badaczkę interesuje przede wszystkim jego obrazowość, która zawiera się w obu typach znaczeń, stąd też widoczne w monografii zrównanie jakości sensów.

Dzięki takim założeniom badawczym folklorystka, pomimo oparcia w źródłach zastanych, może uwzględnić ich nadawczo-odbiorczą specyfikę, która jest podstawą wariantywności ocenianą „,dopiero właściwie w badaniach terenowych”, kiedy zapisywane są ,wszystkie - a nie tylko wybrane przysłowia" (Czubalina, Czubała 1988: 102). Mówiąc o paremiach jako samodzielnych faktach językowych i literackich (Pomierska 2013: 289-330) w kontekście ich artyzmu podkreślanego przez konstrukcje stylistyczne, badaczka uwzględnia prawomocnie i niezwykle ciekawie ich genetyczny związek z żywą mową. Czyni to przede wszystkim w podrozdziale Formuliczność, którego wartości poznawcze docenią nie tylko paremiolodzy, ale i badacze folkloru w ogóle. Przedstawiony w nim sposób analizy i wypracowane wnioski można wykorzystać w genologicznych i funkcjonalnych rozważaniach poświęconych wszystkim gatunkom twórczości słownej.

Jak wspomniałam, drugą część omawianej publikacji tworzy Księga przysłów kaszubskich, na którą składa się około 7300 jednostek, „nie licząc dość licznych mało znaczących odmianek kaszubskich poświadczeń (ujętych zwykle we wspólnym zapisie), wyekscerpowanych z[e] wszystkich możliwych dostępnych dziś źródeł: paremiograficznych, słownikowych i etnograficznych oraz z piśmiennictwa kaszubskiego do 1945 r." (s. 179), w układzie alfabetycznym opartym ,na uznaniu za hasło wyrazu-jądra przysłowia" (s. 347). Zbiór uzupełnia - i ułatwia posługiwanie się nim - selektywny, tj. rejestrujący tylko wyrazy najważniejsze, bezpośrednio związane z warstwą treści i znaczeniem dosłownym, Indeks haset pomocniczych, odsyłający do określonego hasła i numeru przysłowia.

Studium Przysłowia kaszubskie to przystępnie napisanie kompendium wiedzy o paremiografii i paremiologii, ukierunkowane nie deskryptywnie, lecz interpretacyjnie. Jego odbiorca uzyskuje materiał źródłowy oraz pomoc we własnych klasyfikacjach i innych - paremiologicznych i folklorystycznych - analizach. Piękno słowa i lekkość pióra, które stanowią o merytorycznym i poznawczym wnętrzu omawianej publikacji, znalazły odbicie w graficznej oprawie Przysłów... Bogaty materiał ikonograficzny oraz staranność redakcji językowej i technicznej stanowią kropkę nad i. Pozostaje jedynie mieć nadzieję, że polska folklorystyka, rozumiana nie 
jako nauka badająca tylko polskie teksty folkloru, ale i taka, której materią źródłową jest folklor z całego świata, analizowany przez krajowych uczonych, będzie regularnie wzbogacana o tak świetne publikacje. W omawianym tekście nie ma miejsc zbędnych, każdy fragment jest celowy i każdy ma swoje locus w koncepcie autorskim. Justyna Pomierska, jak wnioskuję z jej dzieła, hołduje zasadzie Antoina de Saint-Exupéry’ego, według którego ,inżynier wie, że osiągnął doskonałość nie wtedy, kiedy nie można nic już dodać, ale kiedy nie można nic już zabrać” (Saint-Exupéry 1998: 13).

Joanna Rękas

\section{Literatura}

Adalberg S., 1989-1994, Księga przystów, przypowieści i wyrażeń przystowiowych polskich, Warszawa.

Bartmiński J., 1990, Folklor-język-poetyka, Wrocław-Warszawa-Kraków.

Chitima I.C., 1983, Uniwersalny świat przysłów, przeł. J. Styczyński, w: I.C. Chitima, Literackie studia i szkice rumunistyczno-polonistyczne, red. H. Misterski, Warszawa.

Czubalina M., Czubała D., 1988, Refleksje paremiologiczne, w: Z problemów badania kultury ludowej, red. T. Kłak, Katowice.

Lepa A., 2001, Mity i obrazy, Łódź.

Maślanka J., (red.), 1976, Encyklopedia wiedzy o prasie, Wrocław-Warszawa-Kraków-Gdańsk.

Pisarek W., (red.), 2006, Słownik terminologii medialnej, Kraków.

Pomierska J., 2002 (wyd. II 2010), Przëstowié samò sã rodzy w głowie: Kaszubskie przystowia z polskimi odpowiednikami, Gdańsk.

Pomierska J., 2013, Przystowia kaszubskie. Studium z paremiografii i paremiologii, Gdańsk.

Przybyła-Dumin A., 2013a, Proza folklorystyczna u progu XXI wieku na podstawie badań terenowych. Monografia, Chorzów-Katowice.

Przybyła-Dumin A., 2013b, Proza folklorystyczna u progu XXI. Bajka ludowa. Legenda. Anegdota. Materiaty, Chorzów-Katowice.

Przybyła-Dumin A., 2013c, Proza folklorystyczna u progu XXI. Podanie. Opowieść wspomnieniowa. Legenda wspótczesna. Materiały, Chorzów-Katowice.

Rękas J., 2014, Druga młodość folklorystyki - podjęcie dyskusji, „Literatura Ludowa” nr 4-5, s. 51-59.

Saint-Exupéry A., 1998, Ziemia ojczyzna ludzi, przeł. M. Morstin-Górska, Warszawa. 